\title{
Biodiversity of parasites found in the trahira, Hoplias malabaricus (Bloch, 1794), collected in the Batalha River, Tietê- Batalha drainage basin, SP, Brazil
}

\author{
THAYANA GIÃO, LARISSA S. PELEGRINI, RODNEY K. DE AZEVEDO \& \\ VANESSA D. ABDALLAH
}

\begin{abstract}
Eighty-one Hoplias malabaricus specimens were collected between February 2014 and June 2016. A total of 29 species of metazoan parasites were found, 13 of which were identified as monogeneans, seven were digenean species, seven of which were nematodes, and two of which were from the subclass Hirudinea. The highest prevalence values were presented by Contracaecum sp. and Tylodelphys sp. The highest mean abundance and mean intensity was recorded by Tylodelphys sp.; the values were 36.7 \pm 61.8 and $55.65 \pm 69.1$, respectively. The abundance of the monogenean Urocleidoides cuiabai was found to be positively correlated with host weight. The abundance of Bucephalidae gen. sp. exhibited significant positive correlations with host weight and length. For Contracaecum sp., a significant negative correlation was found between its abundance and host length and weight. No significant differences between the diversity indexes (Margalef, Pielou and Shannon) of the parasites collected in the two points were found. The Sorensen similarity index, with a value of 0.82 between the two sampling points revealed that the parasitic diversity between them is similar. The findings from this study represent new records of occurrence of $H$. malabaricus, as well as of Urocleidoides margolisi, Scleroductus sp. and Helobdella sp.
\end{abstract}

Key words: Characidae, fish parasitology, freshwater parasites, Tietê-Batalha reservoir.

\section{INTRODUCTION}

Studies involving vertebrates in the Neotropical region have been carried out during the last four centuries (Rull 2011). However, considering the lack of studies on invertebrates, especially the parasite communities, several authors supported research on the systematics and diversity of this group (Poulin \& Morand 2004).

Parasites are important for many of their hosts' biological processes, including diet, migration, recruitment, and phylogeny. Parasites may also be direct indicators of environmental quality (Galli et al. 2001). The composition of the parasitic fauna of fish in rivers depends on various factors inherent to each species' habitat, such as the characteristics of the water, as well as on factors inherent to the host, such as each fish's biological and physiological characteristics (Dogiel 1961).

The Tietê River and some of its tributaries, such as the Batalha River, from the TietêBatalha drainage basin, located in the state of São Paulo, Brazil. This basin possesses a drainage area of 3,149 $\mathrm{km}^{2}$, and the Batalha River is $167 \mathrm{~km}$ in length, making it one of the most important tributaries of the Tietê River (Silva et al. 2009). In 2001, the drainage basin of the 
Batalha River was turned into a state Área de Proteção Ambiental (APA). Despite the constant contamination of external agents that affect the river, data from Companhia Ambiental do Estado de São Paulo (CETESB) suggest that the river exhibits good water quality (Santos \& Heubel 2008). The area surrounding the Batalha River and the drainage area suffered from poor use and land occupation by human activities (monocropping, reforestation, and livestock farming, as well as the deposition of sewage, trash, and industrial waste). These activities decreased the amount of native and riparian vegetation, triggering changes in water quality and continuous erosion of the land surrounding the river. The exposure of water sources to this erosion leads to silting on the riverbed, as well as to water pollution (Silva et al. 2009).

This study was performed using the fish species Hoplias malabaricus (Bloch 1794), the trahira. This species occurs in all drainage basins in South America, with the exception of those in the Trans-andine area and of the rivers of Patagonia (Fowler 1950). This species is well adapted to lentic environments, though it may also be found in other types of small and large rivers. It eats plankton in its larval phase, and it is typically piscivorous as an adult, with a limited appetite and large resistance to extended periods without food (Paiva 1974). It has also able to survive in low-oxygen environments, an adaptation which contributes to its wide range (Barbieri 1989). In several waters, H. malabaricus is the only fish that eats a larger prey. It is a lone hunter, and its prey includes species from the families Characidae, Curimatidae, and Cichlidae. It is an ambush predator that lives in benthic habitats and it may be found in rivers and lakes, particularly in shallow waters close to submersed or riparian vegetation. It captures its prey from surface water or midwater during the day (Oliveira 1994). Its reproductive behaviors include the formation of nests in waters with submersed vegetation and parental care provided by males (Prado et al. 2006).

Some parasitology studies considered $\mathrm{H}$. malabaricus specimens collected from different sites around Brazil (Table I), in which a larger number of species belonging to the Monogenea and Digenea classes and to the phylum Nematoda are observed parasitizing this host. As exclusion criterion for the literature review, only species belonging to the groups of parasites identified in the present study were selected (Monogena, Digenea, Nematoda and Hirudinea).

There have been recent studies on fish parasites from the Batalha River; however, only one has compared lentic and lotic environments (Leite 2017). The current study therefore involves a survey of the parasitic fauna of this host, which is of substantial commercial importance. The aims of this study were: 1) to analyze the host's biotic factors and its main habitats with parasitic indexes; 2 ) to identify possible parasite species that may infect humans through the ingestion of raw or undercooked fish; 3) to determine similarities between the parasite species found at the two sampling points; 4) to add knowledge on parasite biodiversity in the state of São Paulo. 
Table I. Records of parasites identified in Hoplias malabaricus (Bloch, 1794) specimens from different locations in Brazil.

\begin{tabular}{|c|c|c|}
\hline Parasite & Location & Reference \\
\hline \multicolumn{3}{|c|}{ Monogenea } \\
\hline \multirow{3}{*}{ Anacanthorus sp. } & Paraná River, Brazil & Graça et al. (2013) \\
\hline & Eastern Amazon basin, Brazil & Ferreira et al. (2017) \\
\hline & Paraná River, Brazil & Graça et al. (2018) \\
\hline $\begin{array}{c}\text { Cosmetocleithrum bulbocirrus Kristsky, } \\
\text { Thatcher and Boeger, } 1986\end{array}$ & Paraná River, Brazil & Graça et al. (2013) \\
\hline \multirow{4}{*}{ Dactilogyridae gen. sp. } & Mogi-Guassu River, Brazil & Kohn et al. (1985) \\
\hline & Brazil & Rosim et al. (2011) \\
\hline & Paraná River, Brazil & Graça et al. (2013) \\
\hline & Eastern Amazon basin, Brazil & Ferreira et al. (2017) \\
\hline Dactylogyrus spp. & Paraíba State, Brazil & Bernadino et al. (2016) \\
\hline $\begin{array}{c}\text { Gyrodactilus trairae Boeger and Popazoglo } \\
1995\end{array}$ & Eastern Amazon basin, Brazil & Ferreira et al. (2017) \\
\hline \multirow{4}{*}{ Monogenea gen. sp. } & Paraná River, Brazil & Takemoto et al. (2009) \\
\hline & Paraná, Brazil & Kohn et al. (2011) \\
\hline & Amazônia Ocidental, Brazil & Malacarne \& Godoi (2012) \\
\hline & Maranhão State, Brazil & Rodrigues et al. (2017) \\
\hline $\begin{array}{c}\text { Vancleaveus janauacaensis Kristsky, Thatcher } \\
\text { and Boeger, } 1986\end{array}$ & Paraná River, Brazil & Graça et al. (2013) \\
\hline \multirow{3}{*}{$\begin{array}{l}\text { Urocleidoides brasiliensis Rosim, Mendoza- } \\
\text { Franco and Luque, } 2011\end{array}$} & Brazil & Rosim et al. (2011) \\
\hline & Paraná River, Brazil & Graça et al. (2013) \\
\hline & Eastern Amazon basin, Brazil & Ferreira et al. (2017) \\
\hline \multirow{4}{*}{$\begin{array}{l}\text { Urocleidoides cuiabai Rosim, Mendoza-Franco } \\
\text { and Luque, } 2011\end{array}$} & Brazil & Rosim et al. (2011) \\
\hline & Paraná River, Brazil & Graça et al. (2013) \\
\hline & Paraná River, Brazil & Gasques et al. (2015) \\
\hline & Eastern Amazon basin, Brazil & Ferreira et al. (2017) \\
\hline \multirow{6}{*}{$\begin{array}{l}\text { Urocleidoides eremitus Kristsky, Thatcher and } \\
\text { Boeger, } 1986\end{array}$} & Perú, Brazil & Iannacone \& Luque (1993) \\
\hline & Brazil & Rosim et al. (2011) \\
\hline & Paraná River, Brazil & Graça et al. (2013) \\
\hline & Amapá, Brazil & Gonçalvez et al. (2016) \\
\hline & Eastern Amazon basin, Brazil & Ferreira et al. (2017) \\
\hline & Amapá, Brazil & Alcântara \& Tavares-Dias (2015) \\
\hline \multirow{3}{*}{$\begin{array}{l}\text { Urocleidoides malabaricusi Rosim, Mendoza- } \\
\text { Franco and Luque } 2011\end{array}$} & Brazil & Rosim et al. (2011) \\
\hline & Paraná River, Brazil & Graça et al. (2013) \\
\hline & Paraná River, Brazil & Gasques et al. (2015) \\
\hline \multirow{2}{*}{$\begin{array}{l}\text { Urocleidoides naris Rosim, Mendoza-Franco } \\
\text { and Luque, } 2011\end{array}$} & Brazil & Rosim et al. (2011) \\
\hline & Eastern Amazon basin, Brazil & Ferreira et al. (2017) \\
\hline
\end{tabular}


Table I. Continuation

\begin{tabular}{|c|c|c|}
\hline Parasite & Location & Reference \\
\hline \multicolumn{3}{|c|}{ Digenea } \\
\hline \multirow{5}{*}{ Austrodiplostomum compactum (Lutz, 1928) } & Paraná River, Brazil & Machado et al. (2005) \\
\hline & Tietê River, Brazil & Paes et al. (2010) \\
\hline & Paraná River, Brazil & Santos et al. (2012) \\
\hline & Doce River, Brazil & Belei et al. (2013) \\
\hline & Paranapanema River, Brazil & Ramos et al. (2013) \\
\hline \multirow{2}{*}{ Austrodiplostomum sp. } & São Francisco River, Brazil & Corrêa et al. (2014) \\
\hline & São Francisco River, Brazil & Costa et al. (2015) \\
\hline Clinostomum complanatum Rudolphi, 1814 & Paraná River, Brazil & Dias et al. (2003) \\
\hline \multirow{2}{*}{ Clinostomum marginatum (Rudolphi, 1819) } & Amapá, Brazil & Gonçalvez et al. (2016) \\
\hline & Amapá, Brazil & Alcântara \& Tavares-Dias (2015) \\
\hline $\begin{array}{c}\text { Clinostomatopsis sorbens (Braun, 1899) } \\
\text { Dollfus1932 }\end{array}$ & Marajó Island, Brazil & Benigno et al. (2014) \\
\hline Dendrorchis neivai Travassos, 1926 & Amapá, Brazil & Gonçalvez et al. (2016) \\
\hline Dendrochis sp. & Santa Maria, Brazil & Weiblen \& Brandão (1992) \\
\hline Digenea gen. sp. & Paraná River, brazil & Takemoto et al. (2009) \\
\hline Diplostomidae gen. sp. & Paraná, Brazil & Kohn et al. (2011) \\
\hline $\begin{array}{l}\text { Genarchella genarchella Kohn \& Fernandes, } \\
1988\end{array}$ & Amapá, Brazil & Gonçalvez et al. (2016) \\
\hline Genarchella sp. & $\begin{array}{l}\text { Quebrada Juan Grande, } \\
\text { Brazil }\end{array}$ & Choudhury et al. (2016) \\
\hline \multirow{6}{*}{$\begin{array}{l}\text { Ithyoclinostomum dimorphum (Diesing,1850) } \\
\text { Witenberg, } 1926\end{array}$} & Chaco Province, Argentina & Szidat (1969) \\
\hline & Santa Maria, Brazil & Weiblen \& Brandão (1992) \\
\hline & $\begin{array}{c}\text { Rio Grande do Sul State, } \\
\text { Brazil }\end{array}$ & Gallio et al (2007) \\
\hline & Lajes Reserve, Brazil & Paraguassú \& Luque (2007) \\
\hline & Doce River, Brazil & Belei et al (2013) \\
\hline & Marajó Island, Brazil & Benigno et al. (2014) \\
\hline Ithyoclinostomum sp. & São Francisco River, Brazil & Costa et al. (2015) \\
\hline Phyllodistomum spatula Odhner, 1902 & São Francisco River, Brazil & Costa et al. (2015) \\
\hline Posthodiplostomum sp. & Amapá, Brazil & Gonçalvez et al. (2016) \\
\hline \multirow{7}{*}{ Pseudosellacotyla lutzi (Freitas, 1941) } & Mogi Guaçu River, Brazil & Kohn et al. (1985) \\
\hline & Mogi Guaçu River, Brazil & Kohn \& Fernandes (1987) \\
\hline & Parana River, Brazil & Fernandes \& Kohn (2001) \\
\hline & Chocó, Colômbia & Perez-Caicedo et al. (2010) \\
\hline & Paraná, Brazil & Kohn et al. (2011) \\
\hline & São Francisco River, Brazil & Costa et al. (2015) \\
\hline & Argentina & Núñez et al. (2017) \\
\hline
\end{tabular}


Table I. Continuation

\begin{tabular}{|c|c|c|}
\hline Parasite & Location & Reference \\
\hline $\begin{array}{l}\text { Sphincterodiplostomum musculosum (Dubois, } \\
\text { 1936) }\end{array}$ & Chaco Province, Argentina & Szidat (1969) \\
\hline Thometrema overstreeti (Brooks et al., 1979) & Perú, Brazil & Iannacone \& Luque (1993) \\
\hline \multirow{2}{*}{ Tylodelphylus s Province1 (Szidat, 1969) } & Chaco Province, Argentina & Szidat (1969) \\
\hline & Santa Maria, Brazil & Weiblen \& Brandão (1992) \\
\hline \multicolumn{3}{|c|}{ Nematoda } \\
\hline Amplicaecum sp. & Mogi Guaçu River, Brazil & Kohn \& Fernandes (1987) \\
\hline Brevimulticaecum sp. & Pantanal, Brazil & Vieira et al. (2010) \\
\hline \multirow{21}{*}{ Contracaecum sp. } & Uruguai & Lent \& Teixeira de Freitas (1948) \\
\hline & Iguaçú River, Brazil & Kohn et al. (1988) \\
\hline & Santa Maria, Brazil & Weiblen \& Brandão (1992) \\
\hline & Barinas State, Venezuela & Moravec et al. (1997) \\
\hline & Jaguari River, Brazil & Madi \& Silva (2005) \\
\hline & Maranhão State, Brazil & Martins et al. (2005) \\
\hline & Lajes Reserve, Brazil & Paraguassú \& Luque (2007) \\
\hline & Córdoba & Pardo et al (2008) \\
\hline & Cuiabá River, Brazil & Barros et al. (2008) \\
\hline & Cuiabá River, Brazil & Barros et al. (2009) \\
\hline & Paraná, Brazil & Kohn et al. (2011) \\
\hline & Marajó Island, Brazil & Benigno et al. (2012) \\
\hline & Pirassununga, Brazil & Corrêa et al. (2013) \\
\hline & Dique Channel, Colombia & $\begin{array}{l}\text { Olivero-Verbel \& Caballero - } \\
\text { Gallardo (2013) }\end{array}$ \\
\hline & Argentina & Mancini et al. (2014) \\
\hline & São Francisco River, Brazil & Corrêa et al. (2015) \\
\hline & Trinidad & Suepaul et al. (2015) \\
\hline & Amapá, Brazil & Gonçalvez et al. (2016) \\
\hline & Dr. João Penido Dam, Brazil & Carvalho et al. (2017) \\
\hline & Amapá, Brazil & Baia et al. (2018) \\
\hline & Amapá, Brazil & Alcântara \& Tavares-Dias (2015) \\
\hline $\begin{array}{l}\text { Contracaecum multipapillatum (von Drasche, } \\
1882 \text { ) }\end{array}$ & Cuiabá River, Brazil & Fontenelle et al. (2017) \\
\hline Cystidicoloides sp. & Amapá, Brazil & Gonçalvez et al. (2016) \\
\hline Eustrongylides ignotus Jäegerskiold, 1909 & Dr. João Penido Dam, Brazil & Carvalho et al. (2017) \\
\hline \multirow{3}{*}{ Eustrongylides sp. } & Paraná River, Brazil & Martins et al. (2009) \\
\hline & Rondonia, Brazil & Meneguetti et al. (2013) \\
\hline & Trinidad & Suepaul et al. (2015) \\
\hline
\end{tabular}


Table I. Continuation

\begin{tabular}{|c|c|c|}
\hline Parasite & Location & Reference \\
\hline Guyanema baudi Petter \& Dlouhy (1985) & Santa Maria, Brazil & Weiblen \& Brandão (1992) \\
\hline $\begin{array}{c}\text { Guyanema raphiodoni Moravec, Kohn and } \\
\text { Fernandes, } 1993\end{array}$ & Paraná, Brazil & Kohn et al. (2011) \\
\hline \multirow{2}{*}{ Nematoda } & Mato Grosso State, Brazil & Barros et al. (2007) \\
\hline & Paraná River, Brazil & Takemoto et al. (2009) \\
\hline $\begin{array}{c}\text { Paracappilaria piscicola Travassos, Artigas \& } \\
\text { Pereria, } 1928\end{array}$ & Santa Maria, Brazil & Weiblen \& Brandão (1992) \\
\hline Parasseuratum soaresi & Santa Maria, Brazil & Weiblen \& Brandão (1992) \\
\hline Physalopteridae gen. sp. & Uruguai & Lent \& Freitas (1948) \\
\hline \multirow{4}{*}{$\begin{array}{c}\text { Procamallanus (Spirocamallanus) inopinatus } \\
\text { Travassos, Artigas and Pereira, } 1928\end{array}$} & Mogi Guaçu River, Brazil & Kohn \& Fernandes (1987) \\
\hline & Amazonas River, Brazil & Baia et al. (2018) \\
\hline & Amapá, Brazil & Gonçalvez et al. (2016) \\
\hline & Amapa & Alcântara \& Tavares-Dias (2015) \\
\hline $\begin{array}{l}\text { Procamallanus (Spirocamallanus) ihering } \\
\text { Travassos, Artigas and Pereira, } 1928\end{array}$ & Mogi Guaçu River, Brazil & Kohn \& Fernandes (1987) \\
\hline \multirow{3}{*}{$\begin{array}{c}\text { Procamallanus (Spirocamallanus) hilarii Vaz } \\
\text { and Pereira, } 1934\end{array}$} & Santa Maria, Brazil & Weiblen \& Brandão (1992) \\
\hline & $\begin{array}{l}\text { Santiago del Estero, } \\
\text { Argentina }\end{array}$ & Ramallo (1997) \\
\hline & Dr. João Penido Dam, Brazil & Carvalho et al. (2017) \\
\hline $\begin{array}{c}\text { Procamallanus (Procamallanus) peraccuratus } \\
\text { Pinto et al. } 1976\end{array}$ & Santa Maria, Brazil & Weiblen \& Brandão (1992) \\
\hline \multicolumn{3}{|l|}{ Hirudinea } \\
\hline \multirow{2}{*}{ Glossiphonidae gen. sp. } & Amapá, Brazil & Gonçalvez et al. (2016) \\
\hline & Lajes Reserve, Brazil & Paraguassú \& Luque (2007) \\
\hline \multirow{2}{*}{ Mizobdella platensis (Cordero, 1933) } & Santa Fé Province, Argentina & Cordero (1933) \\
\hline & & Lopretto (1995) \\
\hline
\end{tabular}

\section{MATERIALS AND METHODS}

\section{Fish and study area}

A total of $81 \mathrm{H}$. malabaricus specimens were collected between February 2014 and June 2016. Fish samples were collected from two sampling points along the Batalha River: the main channel, located in the city of Reginópolis, São Paulo; and the reservoir managed by the Departamento de Água e Esgoto (DAE) of the city of Bauru and located in the town of Piratininga, São Paulo. Fish were captured using simple gillnets of different mesh sizes.
During dissection, data on standard length $(\mathrm{cm})$, weight $(\mathrm{g})$, and sex were recorded. These collections followed the guidelines for scientific fish licensing and were authorized by the Instituto Chico Mendes de Conservação da Biodiversidade (ICMBio) through the Sistema de Autorização e Informação da Biodiversidade (SISBIO) under case number 40998-3.

The section of the Batalha River located in the city of Reginópolis, São Paulo State, Brazil (21053'17"S, 49013'31"W) presents largely lotic characteristics. Though a large part of the area 
is covered by native riparian forest, the area surrounding this stretch of the river is used for agriculture and livestock activities, such as cattle farming, sugarcane crops, cornfields, and eucalyptus groves. These activities result in a large quantity of organic matter and leached pollutants in the water. Another important factor is the lack of sewage treatment in the city. Local raw sewage is released into a tributary of the river (Santos \& Heubel 2008, Sistema Nacional de Informações Sobre Saneamento 2016).

The reservoir managed by the DAE of Bauru is located in the town of Piratininga, São Paulo (22024'46"S, 49-05'05"W) and it has the function to capture water for community supply. The area of the site is approximately $170,000 \mathrm{~m}^{2}$, and water volume is approximately $1,256,40 \mathrm{~m}^{3}$ per month (Departamento de Água e Esgoto de Bauru 2014). The site is characterized as a lentic and intensely anthropized environment (Leite 2017). Activities involving agriculture, livestock farming, and industrial plants occur close to the basin and produced environmental impacts on the basin, including silting, decreases in the already limited native vegetation, and a significant increase in pollutant levels (Leite et al. 2017). Despite these effects, the CETESB considers the water from the basin to be Class 2 water, which means that it is appropriate for human consumption, domestic water supplies, recreation, and protecting aquatic biodiversity (Brasil 2005, São Paulo 2010).

\section{Parasite analysis procedures}

The collection, fixation, conservation, and assembly procedures of parasites were performed based on the methodology provided by Eiras et al. (2006).

The accumulation curve obtained from each river sampling point represents species richness at each site. These curves were calculated using the Bootstrap estimator, which, according to
Poulin (1998), is the best estimator for samples with fewer than 50 hosts. These results allow a comparison between the parasitic communities from each sampling point.

The prevalence, intensity, and abundance of each component of the parasite communities were calculated in accordance with Bush et al. (1997). The relationship between variance and mean parasite intensity (the dispersion index, DI) was calculated for each parasite species in order to determine its aggregation level and the type of distribution of each parasitic infrapopulation. The $d$ statistical test was also performed to determine significance. The Green Index ( $\mathrm{Gl}$ ) was calculated to verify the aggregation level of each parasite species present in the infracommunity (Ludwig \& Reynolds 1988).

The dominance of each component of the parasitic infrapopulations was determined by the dominance frequency and relative dominance (the ratio of the specimens from a given species by the total number of specimens from all of the species in a given infracommunity) using the methodology provided by Rhode et al. (1995).

The Spearman rank correlation coefficient (rs) was used to detect possible correlations between parasite abundance and total host length and weight. The Mann-Whitney $U$ test was applied to determine the effect of the sex of the fish on parasite abundance. Each species of parasite was tested separately (Zar 1999). Student's $t$ test was used to determine differences in mean total length between male and female hosts.

The parasitic diversity of each infracommunity was determined using the Shannon Diversity Index, or $\mathrm{H}$, and the Pielou's index was used to obtain the equitability values (J'). The richness was obtained according to the Margalef index (D) (Zar 1999). One-way ANOVA was performed to verify if there were significant differences between the values of the diversity, 
equitability and richness indexes obtained between the hosts of each river point (Magurran 2013).

The ratio between the sum of heteroxenous and monoxenous parasites species present in the host (H/M) was also calculated. The results were separated by sampling point in order to determine the ecological stability of each environment (Diamant et al. 1999). The similarities between these communities were calculated using the Sorensen Similarity index (Wolda 1981).

All statistical tests were applied only to parasites species with prevalence greater than $10 \%$. The significance level adopted was $p<0.05$. The fish anesthesia and euthanasia methodologies were made following the guidelines of the Conselho Nacional de Controle de Experimentação Animal (CONCEA), and the research project was submitted to the Comitê de Ética no Uso de Animais (CEUA) da Universidade do Sagrado Coração (USC) (authorization no 3295230615) before it could be performed.

\section{RESULTS}

A total of 81 fish were collected, 37 in the reservoir and 44 in the river channel. Only two specimens, in a total of 81 fishes, did not show the presence of parasites. A total of 3,107 parasite specimens were collected, 901 of which were collected in the reservoir (Piratininga) and 2,206 of which were collected from the river channel (Reginópolis). Mean total abundance values for the two sampling points were $24.33 \pm$ 2.4 and $49.92 \pm 6.8$, respectively (Table II). Not all parasites species were found at both sampling points.

A total of 29 species of metazoan parasites were found. Of these, thirteen were monogeneans, six were digenean species in the metacercaria stage, one was a digenean species in the adult stage, seven were nematodes, and two were from the subclass Hirudinea (Table II).

The accumulation curves constructed using mean observed richness $\left(\mathrm{S}_{\text {obs }}\right)$ values and the values from the Bootstrap richness estimator did not reach an asymptote, but they exhibited a tendency to stabilize at approximately 25 species at both sampling points (Figures 1a, b).

In the reservoir managed by the DAE, the Contracaecum sp. larvae exhibited the highest prevalence and frequency of dominant values. In the river channel, the Tylodelphys sp. metacercarie exhibited the highest values (Table III). Regarding the Dispersion Index (DI) and the statistical test $d$ in the DAE reservoir, most of the parasites presented an aggregate distribution pattern, confirmed by the results of the Green Index (GI). Exceptions were Ithyoclinostomum dimorphum, which presented a uniform distribution pattern, and Austrodiplostomum compactum, which presented a random distribution pattern. Meanwhile, in the river channel, all of the parasites presented an aggregate distribution pattern (Table IV).

In the case of Urocleidoides cuiabai, a significant positive correlation was found between its abundance and host length ( $r s=$ 0.37 and $p=0.02$ ) and host weight ( $r s=0.43$ and $p=0.01$ ). For Contracaecum sp., a significant negative correlation was found between its abundance and host length ( $r s=-0.55$ and $p$ $=<0.0001)$ and host weight ( $r s=-0.73$ and $p$ $=<0.0001)$. Both correlations were determined based on samples from the DAE reservoir. In the river channel, only Bucephalidae gen. sp exhibited a significant positive correlation between its abundance and host weight (Table V). The host sex did not influence the parasite abundance at either sampling point (Table VI).

Although the river channel has presented higher average richness and average diversity 
Table II. Prevalence (P), mean abundance (MA) and mean intensity (MI) of parasites of Hoplias malabaricus (Bloch, 1794) captured in the Batalha River, São Paulo State, Brazil, between February 2014 and June 2016.

\begin{tabular}{|c|c|c|c|c|c|c|}
\hline \multirow[t]{2}{*}{ Species } & \multicolumn{3}{|c|}{ Point 1} & \multicolumn{3}{|c|}{ Point 2} \\
\hline & $\mathbf{P}(\%)$ & $\mathrm{MA} \pm \mathrm{SE}$ & $\mathrm{MI} \pm \mathrm{SE}$ & $\mathrm{P}(\%)$ & $\mathrm{MA} \pm \mathrm{SE}$ & $\begin{array}{l}\mathrm{MI} \pm \\
\mathrm{SE}\end{array}$ \\
\hline \multicolumn{7}{|c|}{ Monogenea } \\
\hline Urocleidoides sp. & 2.3 & $0.02 \pm 0.02$ & 1 & - & - & - \\
\hline $\begin{array}{l}\text { Urocleidoides margolisi Molnar, Hanek and } \\
\text { Fernando, } 1974\end{array}$ & 4.5 & $0.1 \pm 0.1$ & $2.5 \pm 2.1$ & - & - & - \\
\hline $\begin{array}{l}\text { Urocleidoides aimarai Moreira, Scholz and } \\
\text { Luque, } 2015\end{array}$ & 2.3 & $0.02 \pm 0.02$ & 1 & 2.7 & $0.03 \pm 0.03$ & 1 \\
\hline Urocleidoides cuiabai & 38.6 & $3.0 \pm 1.05$ & $7.7 \pm 2.3$ & 37.8 & $2.0 \pm 0.5$ & $\begin{array}{c}5.3 \pm \\
0.8\end{array}$ \\
\hline Urocleidoides malabaricusi & 22.7 & $2.0 \pm 0.7$ & $8.7 \pm 2.5$ & 10.8 & $0.4 \pm 0.2$ & $\begin{array}{c}3.5 \pm \\
0.6\end{array}$ \\
\hline Urocleidoides eremitus & 15.9 & $1.6 \pm 0.7$ & $9.8 \pm 3.2$ & - & - & - \\
\hline $\begin{array}{l}\text { Jainus leporini Abdallah, Azevedo and } \\
\text { Luque, } 2012\end{array}$ & 2.3 & $0.02 \pm 0.02$ & 1 & 8.1 & $0.1 \pm 0.3$ & $\begin{array}{c}1.7 \pm \\
0.3\end{array}$ \\
\hline Sciadicleithrum sp. & 2.3 & $0.02 \pm 0.02$ & 1 & 5.4 & $0.1 \pm 0.1$ & $\begin{array}{c}1.5 \pm \\
0.5\end{array}$ \\
\hline Scleroductus sp. & 6.8 & $0.2 \pm 0.14$ & $3 \pm 1.5$ & 2.7 & $0.1 \pm 0.1$ & 3 \\
\hline Anacanthorus sp. & 6.8 & $0.3 \pm 0.2$ & $4.3 \pm 0.7$ & 8.1 & $0.6 \pm 0.5$ & $\begin{array}{c}7.3 \pm \\
5.4\end{array}$ \\
\hline Dactylogyridae gen. sp. & 6.8 & $0.8 \pm 0.5$ & $11.3 \pm 5.5$ & - & - & - \\
\hline Gyrodactilus trairae & 2.3 & $0.1 \pm 0.2$ & 1 & 2.7 & $0.4 \pm 0.4$ & 15 \\
\hline Nothogyrodactylus sp. & 2.3 & $0.04 \pm 0.04$ & 1 & - & - & - \\
\hline \multicolumn{7}{|c|}{ Digenea } \\
\hline Ithyoclinostomum dimorphum & 2.2 & $0.02 \pm 0.03$ & 1 & 27 & $0.3 \pm 0.1$ & $\begin{array}{c}1.1 \pm \\
0.1\end{array}$ \\
\hline Austrodiplostomum compactum & 31.8 & $1 \pm 0.40$ & $3.1 \pm 1$ & 21.6 & $0.3 \pm 0.1$ & $\begin{array}{c}1.4 \pm \\
0.2\end{array}$ \\
\hline $\begin{array}{l}\text { Austrodiplostomum mordax (Szidat and } \\
\text { Nani, 1951) }\end{array}$ & - & - & - & 5.4 & $0.1 \pm 0.1$ & $\begin{array}{c}2.5 \pm \\
0.5\end{array}$ \\
\hline $\begin{array}{l}\text { Phyllodistomum rhandiae (Amato and } \\
\text { Amato, 1993) }\end{array}$ & 29.5 & $1.4 \pm 0.5$ & $4.8 \pm 1.3$ & 2.7 & $0.2 \pm 0.2$ & 6 \\
\hline Tylodelphys sp. & 65.9 & $36.7 \pm 9.3$ & $55.6 \pm 12.8$ & 37.8 & $10.8 \pm 5.7$ & $\begin{array}{c}28.6 \\
\pm \\
14.1\end{array}$ \\
\hline Clinostomum sp. & 4.5 & $0.04 \pm 0.03$ & 1 & - & - & - \\
\hline Bucephalidae gen. sp. & 27.2 & $1.2 \pm 0.5$ & $4.6 \pm 1.3$ & 8.1 & $0.2 \pm 0.1$ & $\begin{array}{c}2.6 \pm \\
1.2\end{array}$ \\
\hline \multicolumn{7}{|c|}{ Nematoda } \\
\hline $\begin{array}{l}\text { Goezia brasiliensis Moravec, Kohn and } \\
\text { Fernandes, } 1994\end{array}$ & - & - & - & 10.8 & $1.0 \pm 0.6$ & $\begin{array}{l}9.0 \pm \\
3.8\end{array}$ \\
\hline
\end{tabular}


Table II. Continuation

\begin{tabular}{|c|c|c|c|c|c|c|}
\hline \multirow[t]{2}{*}{ Species } & \multicolumn{3}{|c|}{ Point 1} & \multicolumn{3}{|c|}{ Point 2} \\
\hline & $\mathbf{P}(\%)$ & $\mathrm{MA} \pm \mathrm{SE}$ & $\mathrm{MI} \pm \mathrm{SE}$ & $\mathbf{P}(\%)$ & $\mathrm{MA} \pm \mathrm{SE}$ & $\begin{array}{c}\mathrm{MI} \pm \\
\mathrm{SE}\end{array}$ \\
\hline Contracaecum sp. & 38.6 & $1.06 \pm 0.4$ & $2.6 \pm 0.7$ & 70.2 & $7.4 \pm 1.5$ & $\begin{array}{r}10.6 \\
\pm 1.8 \\
\end{array}$ \\
\hline Spirox contortus (Rudolphi, 1819) & - & - & - & 2.7 & $0.03 \pm 0.03$ & 1 \\
\hline $\begin{array}{c}\text { Procamallanus (Spirocamallanus) } \\
\text { inopinnatus Travassos, Artigas and Pereira, } \\
1928\end{array}$ & 13.6 & $0.1 \pm 0.07$ & $1.3 \pm 0.3$ & 5.4 & $0.1 \pm 0.1$ & $\begin{array}{c}1.5 \pm \\
0.5\end{array}$ \\
\hline Guyanema baudi Petter and Dloughy, 1985 & - & - & - & 2.7 & $0.03 \pm 0.03$ & 1 \\
\hline $\begin{array}{l}\text { Spinitectus rodolphihering Vaz and Pereira, } \\
1934\end{array}$ & 4.5 & $0.1 \pm 0.1$ & $2.5 \pm 1.5$ & 2.7 & $0.05 \pm 0.05$ & 2 \\
\hline Eustrongylides sp. & - & - & - & 2.7 & $0.03 \pm 0.03$ & 1 \\
\hline \multicolumn{7}{|c|}{ Hirudinea } \\
\hline Placobdella sp. & 2.2 & $0.06 \pm 0.07$ & 3 & 5.4 & $0.08 \pm 0.5$ & $\begin{array}{c}1.5 \pm \\
0.5\end{array}$ \\
\hline Helobdella sp. & 4.5 & $0.09 \pm 0.07$ & $2 \pm 1.5$ & - & - & - \\
\hline
\end{tabular}

Point 1 = Batalha River channel.

Point 2 = Detention basin managed by the Department of Water and Sewage (DAE) of Bauru.

$\mathrm{SE}=$ Standard error.
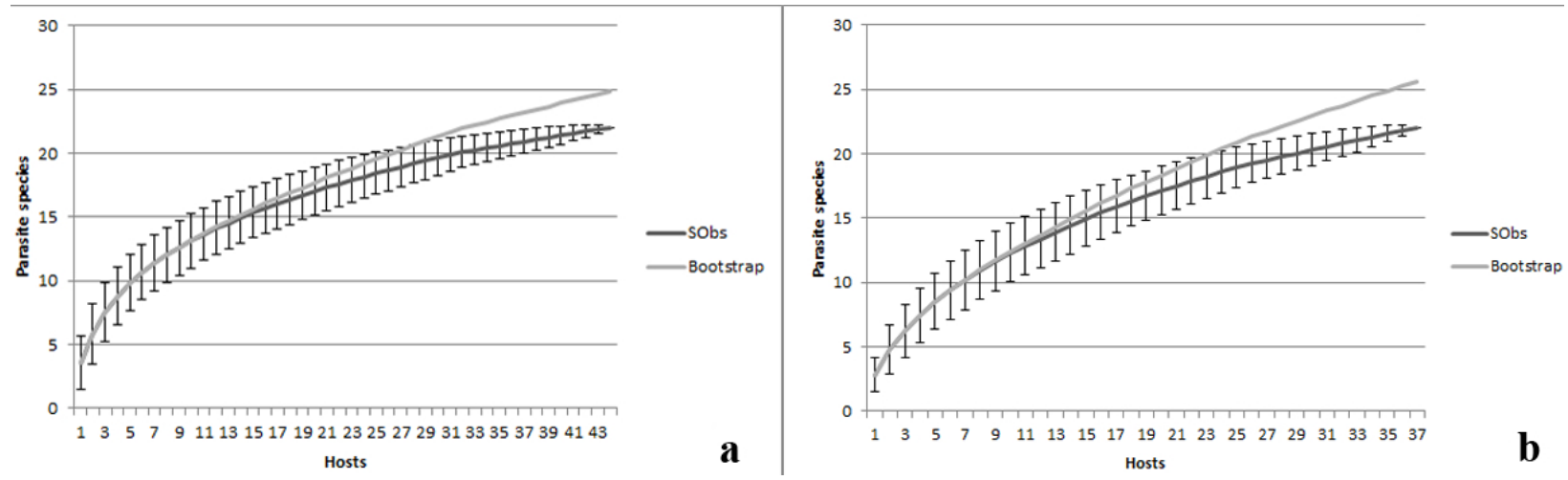

Figure 1. Accumulation curve of species richness observed $\left(\mathrm{S}_{\mathrm{obs}}\right)$ and Bootstrap richness estimates (Bootstrap) of the metazoan parasites in Hoplias malabaricus (Bloch, 1794) collected in the Batalha River in São Paulo State, Brazil. a) The river channel (Sampling Point 1); b) DAE reservoir (Sampling Point 2).

than the DAE reservoir, and the average uniformity has been higher at the river channel point, these values did not present significant differences according to the one-way ANOVA, i.e. the parasitic diversity in the two points is similar (Table VII). Another value that confirms this fact is the Sorensen Similarity Index, with a value of 0.82 between the two sampling points.
The result of the ratio between the sum of heteroxenous and monoxenous parasites found for river channel was 0.93 while in the DAE reservoir was 0.70 . Although the values were different from each other, there were no significant differences between these values when verifying them through the ANOVA oneway test $(p=0.05)$. 


\section{DISCUSSION}

At both sampling points, the parasitic community in $H$. malabaricus was characterized by high species richness but by relatively low diversity and uniformity. As mentioned previously, this fish species is typically piscivorous as an adult.
Its appetite is limited, and it exhibits large resistance to extended periods without food (Paiva 1974), factors which may explain the high parasite richness but low uniformity.

Most of the parasites species showed an aggregate distribution pattern. The exceptions

Table III. Dominance indexes for each component of Hoplias malabaricus (Bloch, 1794) parasitic component community collected at two points on the Batalha River in São Paulo State, Brazil, between February 2014 and June 2016.

\begin{tabular}{|c|c|c|c|c|}
\hline \multirow[t]{2}{*}{ Species } & \multicolumn{2}{|c|}{ Point 1} & \multicolumn{2}{|c|}{ Point 2} \\
\hline & DF (\%) & RD & DF (\%) & RD \\
\hline \multicolumn{5}{|c|}{ Monogenea } \\
\hline Urocleidoides sp. & 0 & 0 & 0 & 0 \\
\hline Urocleidoides margolisi & 0 & 0 & 0 & 0 \\
\hline Urocleidoides aimarai & 0 & 0 & 0 & 0.001 \\
\hline Urocleidoides cuiabai & 6.8 & 0.06 & 2.7 & 0.08 \\
\hline Urocleidoides malabaricusi & 6.8 & 0.04 & 2.7 & 0.01 \\
\hline Urocleidoides eremitus & 2.3 & 0 & 0 & 0 \\
\hline Jainus leporini & 0 & 0.002 & 0 & 0.005 \\
\hline Sciadicleithrum sp. & 0 & 0.03 & 0 & 0.003 \\
\hline Scleroductus sp. & 0 & 0.004 & 0 & 0.003 \\
\hline Anacanthorus sp. & 0 & 0.005 & 0 & 0.02 \\
\hline Dactylogyridae gen. sp. & 0 & 0.01 & 0 & 0 \\
\hline Gyrodactilus trairae & 0 & 0.003 & 0 & 0.02 \\
\hline Nothogyrodactylus sp. & 0 & 0 & 0 & 0 \\
\hline \multicolumn{5}{|c|}{ Digenea } \\
\hline Ithyoclinostomum dimorphum & 0 & 0 & 0 & 0.01 \\
\hline Austrodiplostomum compactum & 4.5 & 0.02 & 0 & 0.01 \\
\hline Austrodiplostomum mordax & 0 & 0.03 & 0 & 0.005 \\
\hline Phyllodistomum rhandiae & 4.5 & 0 & 0 & 0.006 \\
\hline Tylodelphys sp. & 47.7 & 0.7 & 19 & 0.4 \\
\hline Clinostomum sp. & 0 & 0 & 0 & 0 \\
\hline Bucephalidae gen. sp. & 0 & 0.02 & 0 & 0.008 \\
\hline \multicolumn{5}{|c|}{ Nematoda } \\
\hline Goezia brasiliensis & 0 & 0 & 0 & 0.04 \\
\hline Contracaecum sp. & 9.1 & 0.02 & 54 & 0.30 \\
\hline Spirox contortus & 0 & 0 & 0 & 0.001 \\
\hline Procamallanus (Spirocamallanus) inopinnatus & 0 & 0.003 & 0 & 0.003 \\
\hline
\end{tabular}


Table III. Continuation

\begin{tabular}{|c|c|c|c|c|}
\hline Species & \multicolumn{2}{|c|}{ Point 1 } & \multicolumn{2}{c|}{ Point 2 } \\
\hline & DF (\%) & RD & DF (\%) & RD \\
\hline Guyanema baudi & 0 & 0 & 0 & 0.001 \\
\hline Spinitectus rodolphihering & 0 & 0.002 & 0 & 0.002 \\
\hline Eustrongylides sp. & 0 & 0 & 0 & 0.001 \\
\hline & Hirudinea & & & 0 \\
\hline Placobdella sp. & 0 & 0.001 & 0.003 \\
\hline Helobdella sp. & 0 & 0.001 & 0 \\
\hline
\end{tabular}

DF =Dominance frequency.

$\mathrm{RD}=$ Relative dominance.

Point 1 = Batalha River channel.

Point 2 = Detention basin managed by the Department of Water and Sewage (DAE) of Bauru.

Table IV. Dispersion index (DI), Green's index (GI) and statistical test d of each parasite species found in Hoplias malabaricus (Bloch, 1794) specimens collected at two points of the Batalha River in São Paulo State, Brazil, between February 2014 and June 2016.

\begin{tabular}{|c|c|c|c|c|c|c|}
\hline \multirow[t]{2}{*}{ Species } & \multicolumn{2}{|c|}{ Point 1} & \multirow[b]{2}{*}{ GI } & \multicolumn{2}{|c|}{ Point 2} & \multirow[b]{2}{*}{ GI } \\
\hline & DI & d & & DI & d & \\
\hline Urocleidoides cuiabai & 16.31 & 37.32 & 0.35 & 5.11 & 10.78 & 0.11 \\
\hline Urocleidoides malabaricusi & 12.19 & 32.2 & 0.26 & 3.57 & 7.63 & 0.07 \\
\hline Urocleidoides eremitus & 15.01 & 35.81 & 0.32 & - & - & - \\
\hline Austrodiplostomum compactum & 6.13 & 22.77 & 0.11 & 1.28 & 1.20 & 0.007 \\
\hline Phyllodistomum rhandiae & 7.74 & 25.63 & 0.15 & - & - & - \\
\hline Tylodelphys sp. & 104.09 & 94.56 & 2.39 & 111.41 & 22.63 & 3.06 \\
\hline Bucephalidae gen. sp. & 7.85 & 25.8 & 0.15 & - & - & - \\
\hline Ithyoclinostomum dimorphum & - & - & - & 0.90 & -0.36 & 0 \\
\hline Contracaecum sp. & 5.46 & 21.47 & 0.10 & 10.77 & 19.44 & 0.27 \\
\hline Goezia brasiliensis & - & - & - & 13.38 & 22.63 & 0.34 \\
\hline Procamallanus (Spirocamallanus) inopinnatus & 1.60 & 11.36 & 0.01 & - & - & - \\
\hline
\end{tabular}

Point 1 = Batalha River channel.

Point 2 = Detention basin managed by the Department of Water and Sewage (DAE) of Bauru.

were Ithyoclinostomum dimorphum, which presented an uniform distribution pattern, and Austrodiplostomum compactum, which presented a random distribution pattern. Both species were collected from the same sampling point, but this finding is a result of the low collected number of individuals of these species. According to Zuben (1997), a uniform distribution pattern may be a result of factors such as parasite and host mortality, which would result in a more uniform distribution of parasitic metazoan, thus reducing their aggregation level. Environmental factors are those that have the largest impact on aggregate distribution. These factors include changes in the physical parameters of the environment, and differences 
Table V. Correlation between parasitic abundance and standard length (SL) and weight (W) of Hoplias malabaricus Bloch, 1794 specimens collected at two points on the Batalha River in São Paulo State, Brazil, between February 2014 and June 2016.

\begin{tabular}{|c|c|c|c|c|c|c|c|c|}
\hline \multirow[t]{3}{*}{ Species } & \multicolumn{4}{|c|}{ Point 1} & \multicolumn{4}{|c|}{ Point 2} \\
\hline & \multicolumn{2}{|c|}{ Abundance $\times \mathrm{SL}$} & \multicolumn{2}{|c|}{ Abundance $\mathrm{x}$ W } & \multicolumn{2}{|c|}{ Abundance $x$ SL } & \multicolumn{2}{|c|}{ Abundance $\mathrm{x}$ W } \\
\hline & rs & (p) & rs & (p) & rs & (p) & rs & (p) \\
\hline Urocleidoides cuiabai & -0.15 & 0.90 & -0.21 & 0.18 & 0.37 & $0.02^{*}$ & 0.43 & $0.01^{*}$ \\
\hline Urocleidoides malabaricusi & -0.15 & 0.34 & -0.21 & 0.18 & 0.10 & 0.54 & 0.13 & 0.45 \\
\hline Urocleidoides eremitus & -0.14 & 0.37 & -0.22 & 0.15 & - & - & - & - \\
\hline $\begin{array}{l}\text { Austrodiplostomum } \\
\text { compactum }\end{array}$ & -0.01 & 0.96 & 0.11 & 0.47 & 0.18 & 0.28 & 0.25 & 0.13 \\
\hline Phyllodistomum rhandiae & 0.25 & 0.09 & 0.25 & 0.11 & - & - & - & - \\
\hline Tylodelphys sp. & 0.02 & 0.90 & 0.10 & 0.52 & 0.25 & 0.13 & 0.29 & 0.08 \\
\hline Bucephalidae gen. sp. & 0.27 & 0.08 & 0.30 & $0.04^{*}$ & - & - & - & - \\
\hline $\begin{array}{l}\text { Ithyoclinostomum } \\
\text { dimorphum }\end{array}$ & - & - & - & - & 0.00 & 0.99 & 0.01 & 0.97 \\
\hline Contracaecum sp. & 0.04 & 0.78 & 0.02 & 0.90 & -0.55 & $<0.0001^{\star}$ & -0.73 & $<0.0001^{*}$ \\
\hline Goezia brasiliensis & - & - & - & - & -0.20 & 0.23 & -0.18 & 0.30 \\
\hline $\begin{array}{l}\text { Procamallanus } \\
\text { (Spirocamallanus) } \\
\text { inopinnatus }\end{array}$ & -0.05 & 0.77 & 0.03 & 0.85 & - & - & - & - \\
\hline
\end{tabular}

Point 1 = Batalha River channel.

Point 2 = Detention basin managed by the Department of Water and Sewage (DAE) of Bauru.

$r s=$ Spearman rank correlation coefficient.

* $=$ Value with significance levels of $p<0.05$.

$p=$ significance level.

in host susceptibility to infection, which may be a consequence of immunological differences (Zuben 1997).

A total of 29 species of parasites were collected, the majority of which (15) were ectoparasites from the class Monogenea. These are hermaphrodites and present a direct life cycle that contributes to parasitic reinfestation (Domingues 2004). Another characteristic that contributes to this result is the fact that the parasites of this class have morphological adaptations that allow their fixation in the substrate (Yamada et al. 2007), facilitating its infestation in the hosts, since this fish species presents benthic habits, being found in rivers and lagoons (Oliveira 1994). Fish of the order Characiformes present greater monogeneans abundance (Boeger \& Vianna 2006), and besides being a representative of the Characiformes, it also feeds on prey included in this same order (Oliveira 1994). These facts may explain this result, since as they are ingesting the prey, its body surface come into contact with the oral cavity, gills and palate of the host, facilitating the parasite infestation.

The most frequent monogeneans in the host were Urocleidoides eremitus and Urocleidoides malabaricusi. Most of the specimens found from these species parasitized the hosts gills. The genus Urocleidoides does not exhibit host 
Table VI. Effect of the sex of the Hoplias malabaricus (Bloch, 1794) specimens collected between February 2014 and June 2016 at two points on the Batalha River in São Paulo State, Brazil, on the parasite abundance of each parasite species.

\begin{tabular}{|c|c|c|c|c|}
\hline Species & \multicolumn{2}{|c|}{ Point 1 } & \multicolumn{2}{c|}{ Point 2 } \\
\hline & $\mathbf{Z}(\mathbf{U})$ & $\mathbf{p}$ & $\mathbf{Z}(\mathbf{U})$ & $\mathbf{p}$ \\
\hline Urocleidoides cuiabai & 0.73 & 0.22 & 13.4 & 0.09 \\
\hline Urocleidoides malabaricusi & 0.46 & 0.31 & 0.51 & 0.31 \\
\hline Urocleidoides eremitus & 0.15 & 0.43 & - & - \\
\hline Austrodiplostomum compactum & 0.49 & 0.31 & 0.39 & 0.35 \\
\hline Phyllodistomum rhandiae & 0.1 & 0.45 & - & - \\
\hline Ithyoclinostomum dimorphum & - & - & 0.15 & 0.43 \\
\hline Tylodelphys sp. & 0.12 & 0.44 & 0.39 & 0.35 \\
\hline Bucephalidae gen. sp. & 0.55 & 0.29 & - & - \\
\hline Goezia brasiliensis & - & - & 10.4 & 0.15 \\
\hline Contracaecum sp. & 0.43 & 0.33 & 0.19 & 0.42 \\
\hline Procamallanus (Spirocamallanus) inopinnatus & 10.44 & 0.14 & - & - \\
\hline
\end{tabular}

Point 1 = Batalha River channel.

Point 2 = Detention basin managed by the Department of Water and Sewage (DAE) of Bauru.

$p=$ Significance level.

$\mathrm{Z}(\mathrm{U})=$ Mann-Whitney $\mathrm{U}$ test.

Table VII. Diversity indexes of the metazoan parasite communities in Hoplias malabaricus (Bloch, 1794) specimens collected between February 2014 and June 2016 at two points on the Batalha River in São Paulo State, Brazil ( $D$ = species richness according to the Margalef index; $\mathrm{H}=$ Brillouin diversity; $\mathrm{J}^{\prime}=$ Pielou's evenness index; $\mathrm{H} / \mathrm{M}=$ ratio between the sum of heteroxenous and of monoxenous parasites). All means followed by \pm standard deviation.

\begin{tabular}{|c|c|c|}
\hline & Point 1 & Point 2 \\
\hline D & $0.75 \pm 0.59$ & $0.68 \pm 0.48$ \\
\hline$H$ & $0.54 \pm 0.45$ & $0.50 \pm 0.34$ \\
\hline J' & $0.51 \pm 0.35$ & $0.59 \pm 0.33$ \\
\hline H/M & 0.93 & 0.70 \\
\hline
\end{tabular}

Point 1 = Batalha River channel.

Point 2 = Detention basin managed by the Department of Water and Sewage (DAE) of Bauru.

specificity and may be found in fish of different orders, including Siluriformes, Characiformes, Gymnotiformes, and Cyprinodontiformes (Eiras et al. 2010). However, Graça et al. (2013) and Cohen et al. (2013) report that U. cuiabai, U. malabaricusi, $U$. brasiliensis, and $U$. eremitus have thus far been detected only in $H$. malabaricus, a finding which suggests a specificity for this species.
Contracaecum sp. was the most frequent species in the hosts collected from the river channel. It was found infecting four sites: the abdominal cavity, the stomach, the liver, and the intestine. Nematodes belonging to the family Anisakidae have been recognized for their zoonotic potential: when their larvae are ingested with raw or undercooked fish, they 
may cause a disease known as anisakiasis (Moreno-Ancillo et al. 1997). Shamsi \& Butcher (2011) reported the occurrence of this disease in Australia, where a woman was infected by nematodes of the species Contracaecum sp. and presented symptoms such as vomiting, diarrhea and gastrointestinal pain. Another species of substantial zoonotic importance is Eustrongylides sp. Though there are no reports of its infection in humans in Brazil, it is a risk to human health since this species can also causes anisakiasis (Barros et al. 2007, 2009).

Tylodelphys sp. metacercariae presented a high value of frequency in the DAE reservoir. It was the second most prevalent species found in the hosts, and it exhibited three sites of infection: the eyes, the intestine, and the abdominal cavity of the fish. Larvae of this species have been found in H. malabaricus, as reported by Szidat (1969). Intense infection by diplostomid species in fish eyes can result in blindness and cataracts, impairing the host's vision and making it more vulnerable to being preyed by piscivorous birds (Owen et al. 1993, Pavanelli et al. 2008).

Significant positive correlations between parasite abundance and host weight and length were found in the cases of U. cuiabai and Bucephalidae gen. sp. According to Pavanelli et al. (2004), this relationship may be influenced by factors such as fish age, changes in their diet and in the food consumed by fish in each age group, and the life cycles of the parasites. The positive correlation between Bucephalidae gen. sp. abundance and host weight occurs due $H$. malabaricus can act as intermediary host for digeneans. This group of parasites present a heteroxenous life cycle: crustaceans are their first intermediate hosts, followed by fish, which are part of the host's diet, and their final hosts, which are birds and both aquatic and land mammals (Carnevia et al. 2005). Minhos et al. (2016) reported the same positive correlation between digenean parasite species and $H$. malabaricus specimens collected in riparian ponds established in the Miranda-Abobral subregion, located in the Pantanal region of Mato Grosso do Sul State, Brazil. The authors attribute this positive correlation to the fact that digeneans present a wide geographical distribution and have adaptation strategies involving asexual reproduction.

Urocleidoides cuiabai infestation was also found to be positively correlated with host length and weight; the weight host would be directly associated with host length in most cases, which means that the larger the host's body surface area and gills cavity are, the larger the site of monogenean infestation tends to be (Rohde et al. 1993). Alcântara \& Tavares-Dias (2015) identified the same positive correlation between a Monogenea species and $H$. malabaricus from the Igarapé Fortaleza basin, located in the State of Amapá, in the Eastern Amazon region of Brazil.

Contracaecum sp. infection was found to share a significant negative correlation with host weight and length. This result may be explained by the diet changes that occur during fish development, causing to the fish in certain stages of development to stop feeding on some animals that act as first intermediate host in the Contracaecum sp. life cycle (Luque \& Chaves 1999. Adams 1985). It can also be explained by increased immunity by the fish ages, since older individuals can eliminate the parasites through immune system mechanism (Iyaji et al. 2009). Duarte et al. (2016) reported this type of correlation with Contracaecum sp. infestation in a study on Salminus hilarii Valenciennes, 1850 collected from the São Francisco River in Brazil, as well as by Hoshino (2013) in a study on Metynnis lippincottianus Cope, 1870 collected from in the Igarapé Fortaleza basin in Amapá State, Brazil. Meanwhile, Carvalho et al. (2017) found a positive correlation between $\mathrm{H}$. 
malabaricus and Contracaecum sp. abundance in fish analyzed from the Dr. João Penido Dam, located in the city of Juiz de Fora, Minas Gerais State, Brazil. The authors also reported a high prevalence of Contracaecum sp. larvae in their study: larval prevalence was $77.5 \%$, which is close to the $70.2 \%$ rate of abundance found in the DAE reservoir in the current study.

The sex of the hosts did not influence parasitism in the present study. According to Azevedo et al. (2007), this finding may mean that males and females' ecological relationships are similar. Though the male $H$. malabaricus cares for the offspring (Prado et al. 2006), this behavior did not result in differences in parasitism between the sexes. Madi \& Silva (2005) found the same results in $\mathrm{H}$. malabaricus specimens collected from the Jaguari Reservoir in Brazil. Benigno (2011) also reported no influence of sex on the parasitism of $\mathrm{H}$. malabaricus collected from Lake Arari in Pará State, Brazil. In contrast to these findings, however, Corrêa (2014) performed a parasitological survey of $\mathrm{H}$. malabaricus in the basins of the Grande River and Mogi Guaçu River in Brazil and found females to be more parasitized than males, contributing this result to the fact that females spend more energy in the reproductive period, feeding more and becoming more vulnerable to infection.

Communities may differ in their species diversity values due to differences in the distribution of relative abundance or to differences in the number of specimens collected (Denslow 1995). These differences may reflect biologically significant patterns resulting from resource availability or conditions for growth (Gotelli \& Colwell 2001). For many taxa, the greater the number of individuals sampled is, the greater the number of species recorded will be (Bunge \& Fitzpatrick 1993) because it will also contemplate the sampling of rare species. The influence of the sample effort will be related to other factors inherent to the host (such as age, weight, sex, eating habits, immunity, etc.), and all these factors will be responsible for the composition of the parasite community. However, a spatiotemporal pattern in studies with fish parasitology is scarcely observed (Yamada \& Takemoto 2017), and most parasitic populations are dominated by stochastic events (Price 1980). Perhaps, this factor explains the lack of stabilization of the accumulation curves for the parasite species found in the current study.

Environmental conditions are of great importance for the survival and welfare of the host. However, they directly affect the parasites species that depend on it to complete its life cycle (Sures et al. 2017). Changes in their chemical composition and physiology, as well as their prevalence and intensity values, are consequences of changes in the habitat of these organisms, recognized as bioindicator species (Lafferty 1997, Vidal-Martinez et al. 2010). This type of interaction can be observed in relation to the value presented by the ratio between the sum of heteroxenous parasites and monoxenous parasites (Diamant et al. 1999). Significant differences were expected between the results presented by the ratio $(H / M)$ of each point. However, when checking the values with one-way ANOVA, this difference was not significant. Although the two points suffers with anthropic actions, the reservoir of DAE presents characteristics of a lentic environment, which could increase the "damages" resulting from the modifications in the structure of the environment due to the damn present on the local. Environments located upstream of dams suffer from the intensification of processes such as sedimentation and eutrophication, affecting the local aquatic fauna (Agostinho et al. 2016, Affonso et al. 2016). According to Portella et al. (2017), reduction in environmental quality results in a decrease in the richness, equitability and 
diversity of species due to lack of resources and inter and intraspecific competition generated by it.

A relatively high rate of similarity was found between the parasite species collected from the two sampling points, due to the fact that this index varies between 0 (zero similarity) and 1 (maximum similarity), and a value of 0.82 was found. Although there is a considerable distance between the sampling points (135 km), the high similarity in the composition and abundance of the parasitic fauna at the two sampling points is likely due to the fact that they are both located along the Batalha River. This connection is responsible for the transport and transfer of aquatic organisms such as parasitic metazoa, organic matter, and energy between the sampling points (Freeman et al. 2007).

In general, the parasitic fauna of $H$. malabaricus was characterized by a high species richness with a predominance of ectoparasites, and there was no significant difference between the parasitic infracommunities sampled at the two collection points. Based on the results obtained herein, the metazoan species U. margolisi, Scleroductus sp., and Helodbella sp. are being reported in this host for the first time. The species Anacanthorus sp., Nothogyrodactylus sp., G. trairae, Bucephalidae gen. sp., A. mordax, Tylodelphys sp., and Eustrongylides are being reported in the Batalha River for the first time, a finding which expands the geographic distribution of these parasites and contributing to the global biodiversity inventory of fish parasites (Leite 2017, Negrelli et al. 2018, Pelegrini et al. 2018).

\section{Acknowledgments}

We would like to thank Danielle Derimo Cosimo for translating this work. Thayana Gião received a research grant from the Fundação de Amparo à Pesquisa do Estado de São Paulo (FAPESP; case number 2015/17932-9).
Vanessa D. Abdallah received a research project grant from FAPESP (2012/23655-0).

\section{REFERENCES}

ADAMS AM. 1985. Parasites on the gills of the Plains Killifish, Fundulus kansae, in the South Platte River, Nebraska. Trans Am Microsc Soc 104(3): 278-284.

AFFONSO IP, GOMES LC, AGOSTINHO AA, MESSAGE HJ, LATINI JD \& GARCIA-BERTHOU E. 2016. Interacting effects of spatial gradients and fishing gears on characterization of fish assemblages in large reservoirs. Rev Fish Biol Fisher 26(1): 71-81.

AGOSTINHO AA, GOMES LC, SANTOS NCL, ORTEGA JCG \& PELICICE FM. 2016. Fish assemblages in Neotropical reservoirs: colonization patterns, impacts and management. Fish Res 173(1): 26-36.

ALCÂNTARA NM \& TAVARES-DIAS M. 2015. Structure of the parasites communities in two Erythrinidae fish from Amazon River system (Brazil). Rev Bras Parasitol Vet 24(2): 183-190.

AYRES M, AYRES JR M, AYRES DL AND SANTOS AS. 2007. BioEstat 5 - versão 5.3. Belém: Instituto de Desenvolvimento Sustentável Mamirauá, $5^{a}$ ed., 364 p.

AZEVEDO RK, ABDALLAH VD \& LUQUE JL. 2007. Quantitative aspects of metazoan parasites communities of American harvestfish, Peprilus paru (Linnaeus, 1758) (Perciformes: Stromateidae), from the coastal zone of the State of Rio de Janeiro, Brazil. Rev Bras Parasitol Vet 16(1): 10-14.

BARBIERI G. 1989. Dinâmica da reprodução e crescimento de Hoplias malabaricus (Bloch, 1794) (Osteichthyes, Erythrinidae) da Represa de Monjolinho, São Carlos/ SP. Rev Brasil Biol 6(2): 225-233.

BARROS LA, MORAES FILHO I \& OLIVEIRA RL. 2007. Larvas de nematóides de importância zoonótica encontradas em traíras (Hoplias malabaricus Bloch, 1794) no município de Santo Antonio do Leverger, MT. Arq Bras Med Vet Zootec 59(2): 533-535.

BARROS LA, OLIVEIRA RL, MORAES FILHO J, JUSTINO CHS \& MATEUS LAF. 2009. Análise do parasitismo por Contracaecum sp. e Eustrongylides sp. em cacharas, Pseudoplatystoma fasciatum (Linnaeus, 1766) (Pisces: Pimelodidae) provenientes do rio Cuiabá, Mato Grosso, Brasil. RBCV 16(2): 58-61.

BARROS LA, SIGARINI CO \& PINTO PR. 2008. Resistence of Contracaecum sp. larvae under low temperature. R Bras Ci Vet 15(3): 143-145. 
BELEI F, FERREIRA SR, PERIN LM, BRAGA FR, SAMPAIO WMS, ARAÚJO JV, DERGAM JA \& TAKEMOTO RM. 2013. First report of Autrodiplostomum compactum and Ithyoclinostomum dimorphum in the trahira (Hoplias malabaricus) from the middle course of the Rio Doce, Minas Gerais, Brazil. Arqu Inst Biol 80(2): 249-252.

BENIGNO RNM. 2011. Helmintos de interesse higiênicosanitário coletados em Hoplerytrinus unitaeniatus, Hoplias malabaricus e Pygocentrus nattereri (Pisces Characiformes) procedentes do lago Arari (ilha de Marajó), Pará - Brasil. Doctoral Thesis, Universidade Federal Fluminense.

BENIGNO RNM, CLEMENTE SC, MATOS ER, PINTO RM, GOMES DC \& KNOFF M. 2012. Nematodes in Hoplerytrinus unitaeniatus, Hoplias malabaricus and Pygocentrus nattereri (Pisces Characiformes) in Marajó Island, Brazil. Rev Bras Parasitol Vet 21(2): 165-170.

BENIGNO RNM, KNOFF M, MATOS ER, GOMES DC, PINTO RM \& SÃO CLEMENTE SC. 2014. Morphological aspects of Clinostomidae metacercarie (Trematoda: Digenea) in Hoplerytrinus unitaeniatus and Hoplias malabaricus (Pisces: Erythrinidae) of the Neotropical region, Brazil. An Acad Bras Cienc 86: 733-744.

BERNADINO MGS, SILVA EG, BEZERRA TIC, LUCENA RB \& SATAKE F. 2016. Ectoparasitologic, hematologic and histopathologic assessment of Hoplias malabaricus Bloch, 1794 from ponds located in Sumé municipality, state of Paraíba, Brazil. Pesq Vet Bras 36(7): 581-586.

BOEGER WA \& VIANNA RT. 2006. Monogenoidea. In: Thatcher VE (Ed),Amazon Fish Parasites. Sofia: Pensoft Publishers, $2^{a}$ ed., 508p.

BRASIL. 2005. MINISTÉRIO DO MEIO AMBIENTE. RESOLUÇÃO CONAMA N 357, DE 17 DE MARÇO DE 2005, BRASílLIA. Dispõe sobre a classificação dos corpos de água e diretrizes ambientais para o seu enquadramento, bem como estabelece as condições e padrões de lançamento de efluentes, e dá outras providências. Disponível em http://www.mma.gov.br/port/conama/res/res05/ res35705.pdf\&gt;. Acessado em 18/03/2017.

BUNGE J \& FITZPATRICK M. 1993. Estimating the number of species; a review. J Am Statist Assoc 88(421): 364-373.

BUSH AO, LAFFERTY KD, LOTZ J \& SHOSTAK AW. 1997. Parasitology meets ecology on its own terms: Margolis et al. revisited. American Society of parasitologists. J Parasitol 83(4): 575-583.

CARNEVIA D, CASTRO O, PERRETA A \& VENZAL JM. 2005. Identificación en Uruguay de metacercarias de Ascocotyle (Phagicola) longa Digena: Heterophyidae parasitando lisas, Mugil platanus Pisces: Mugilidae y evaluación del riesgo de zoonosis y afecciones en mascotas. Rev SMVU 40(1): 159-160.

CARVALHO AR, MARTINS RT, BELLEI PM \& LIMA SS. 2017. Ecological aspects of helminth fauna of Hoplias malabaricus (Bloch, 1794) (Characiformes, Erythrinidae) of Dr. João Penido Dam (Juiz de Fora- MG, Brazil). Rev Brasil Zoo 18: 7-20.

CHOUDHURY A, GARCIA-VARELA M \& DE LEON GPP. 2016. Parasites of freshwater fishes in the Great American Biotic Interchange: a bridge too far? J Helminthol 91(2): 174-196.

COHEN SC, JUSTO MC \& KOHN A. 2013. South American Monogenoidea Parasites of Fishes, Amphibians and Reptiles. Rio de Janeiro: Oficina de livros 1: 663.

CORDERO EH. 1933. Notes on the leeches. II. Piscicola platense n. sp. of South American fish Hoplias malabaricus (Bloch). Ann Parasitol Hum. Comp 11: 450-462.

CORRÊA LL. 2014. Parasitos de Prochilodus lineatus, Hoplias aff. malabaricus e Clarias gariepinus das bacias do rio Grande e Mogi-Guaçu, Estado de São Paulo, Brasil. Doctoral Thesis, Universidade Estadual de Campinas, $95 \mathrm{p}$.

CORRÊA LL, BASTOS LAD, CECCARELLI PS \& DOS REIS NS. 2015. Hematological and histopathological changes in Hoplias malabaricus from the São Francisco River, Brazil caused by larvae of Contracaecum sp. (Nematoda: Anisakidae). Helminthologia 52(2): 96-103.

CORRÊA LL, KARLING LC, TAKEMOTO RM, CECCARELLI PS \& UETA MT. 2013. Hematological alterations caused by high intensity of $\mathrm{L}_{3}$ larvae of Contracaecum sp. Railliet \& Henry, 1912 (Nematoda, Anisakidae) in the stomach of Hoplias malabaricus in lakes in Pirassununga, São Paulo. Parasitol Res 112(8): 2783-2789.

COSTA CPD, MONTEIRO MC \& SATO BCM. 2015. Digenea de Hoplias intermedius e Hoplias malabaricus (Actinopterygii, Erythrinidae) do alto rio São Francisco, Brasil. Rev Bras Parasitol Vet 24(2): 129-135.

DA GRAÇA RJ, FABRIN TMC, GASQUES LS, PRIOLI SMAP, BALBUENA JÁ, PRIOLI AJ \& TAKEMOTO RM. 2018. Topological congruence between phylogenies of Anacanthorus spp. (Monogenea: Dactylogyridae) and their Characiformes (Actinopterygii) hosts: A case of host-parasite cospeciation. PLoS ONE 13(3): e0193408.

DENSLOW J. 1995. Disturbance and diversity in tropical rain forests: the density effect. Ecol Appl 5(4): 962-968.

DEPARTAMENTO DE ÁGUA E ESGOTO DE BAURU. 2014. Rio Batalha e a Lagoa, 2014. Disponivel em: http:// 
www.daebauru.com.br/2014/empresa/empresa.php\&gt. Acessado em: 18/03/2017.

DIAMANT A, BANET A \& PAPEMA I. 1999. The use of fish metabolic, pathological and parasitological indices in pollution monitoring. II. The Red Sea and Mediterranean. Helgol Mar Res 53(3-4): 195-208.

DIAS MLGG, EIRAS JC, MACHADO MH, SOUZA GTR \& PAVANELLI GC. 2003. The life cycle of Clinostomum complanatum Rudolphi, 1814 (Digenea, Clinostomidae) on the floodplain of the high Paraná river, Brazil. Parasitol Res 89(6): 506-508.

DOGIEL VA. 1961. Ecology of the parasites of freshwater fishes. In: Dogiel VA, Petrushevski GK \& Polyanski YI. Parasitology of fishes (Eds), Edinburg and London, p. 117-139.

DOMINGUES MR. 2004. Filogenia e taxonomia de Diplectanidae Monticelli, 1903 (Platyhelminthes; Monogenoides). Masters Dissertation. Universidade Federal do Paraná, 217 p.

DUARTE R, SANTOS-CLAPP MD \& BRASIL-SATO MC. 2016. Endohelminthes of Salminus hilarii Valenciennes (Actinopterygii: Bryconidae) and their ecological descriptors in the upper São Francisco River, Brazil. Rev Bras Med Vet 38(3): 194-205.

EIRAS JC, TAKEMOTO RM \& PAVANELLI GC. 2006. Métodos de estudo e técnicas laboratoriais em parasitologia de peixes. $2^{a}$ ed., Maringá: Universidade Estadual de Maringá, 171 p.

EIRAS JC, TAKEMOTO RM \& PAVANELLI GC. 2010. Diversidade dos parasitos de peixes de água doce do Brasil. Maringá: Clichetec, $1^{\mathrm{a}}$ ed., $250 \mathrm{p}$.

FERNANDES BMM \& KOHN A. 2001. On some trematodes parasites of fishes from Paraná river. Braz J Biol 61(3): 461-466.

FERREIRA KDC, RODRIGUES ARO, CUNHA JM \& DOMINGUES MV. 2017. Dactylogyrids (Platyhelminthes, Monogenoidea) from the gills of Hoplias malabaricus (Characiformes: Erythrinidae) from coastal rivers of the Oriental Amazon Basin: species of Urocleidoides and Constrictoanchoratus n. gen. J Helminthol 92(3): 353-368.

FONTENELLE G, KNOFF M, VERÍCIMO MA \& SÃO CLEMENTE SC. 2017. Epicutaneous sensitization with nematode antigens of fish parasites results in the production of specific IgG and IgE. J Helminthol 92(4): 403-409.

FOWLER HW. 1950. Os peixes de água doce do Brasil. Arq Zool Estado de São Paulo 6: 205-404.
FREEMAN MC, PRINGLE CM \& JACKSON CR. 2007. Hydrologic connectivity and the contributions of stream headwaters to ecological integrity at regional scales. J Am Water Resour Assoc 43(1): 5-14.

GALLI P, CROSA G, MARINIELLO L ORTIS M \& D'AMELIO S. 2001. Water quality as a determinant of the composition of fish parasites communities. Hydrobiologia 452(1): 173-179.

GALLIO M, SILVA AS, SOARES JF, SILVA MK, SALOMÃO EL \& MONTEIRO SG. 2007. Ocorrência de metacercárias de Ithyoclinostomum dimorphum em traíras no Rio Grande do Sul, Brasil. Estud Biol 29(68): 337-339.

GASQUES LS, GRAÇA RJ, PRIOLI SMAP, TAKEMOTO RM \& PRIOLI AJ. 2015. Molecular characterization of Urocleidoides cuiabai and U. malabaricusi (Monogenea: Dactylogyridae) from the trahira fish Hoplias aff. malabaricus in the Paraná River, Brazil. J Helminthol 90(6): 693-697.

GONÇALVEZ RA, OLIVEIRA MSB, NEVES LR \& TAVARES-DIAS M. 2016. Seasonal pattern in parasite infracommunities of Hoplerythrinus unitaeniatus and Hoplias malabaricus (Actinopterygii: Erythrinidae) from the Brazilian Amazon. Acta Parasitol 61(1): 119-129.

GOTELLI N \& COLWELL RK. 2001. Quantifying biodiversity: Procedures and pitfalls in the measurement and comparison of species richness. Ecol Lett 4: 379-391.

GRAÇA RJ, HUEDA BH, ODA FH \& TAKEMOTO RM. 2013. Monogenea (Platyhelminthes) parasites from the gills of Hoplias aff. malabaricus (Bloch, 1794) (Pisces: Erythrinidae) in the Upper Paraná River Floodplain, States of Paraná and Mato Grosso do Sul, Brazil. Check List 9(6): 1484-1487.

HOSHINO MDFG. 2013. Parasitofauna em Peixes Characidae e Acestrorhynshidae da Bacia do Igarapé Fortaleza, Estado do Amapá, Amazônia Oriental. Masters Dissertation, Universidade Federal do Amapá, 86 p.

IANNACONE J \& LUQUE JL. 1993. New records of helminths parasitic on Peruvian Amazonian fishes (Ostheichthyes). Biol Trop 41(2): 303-305.

IYAJI F, ETIM L \& EYO J. 2009. Parasite Assemblages in Fish Host. Bio-Research 7(2): 561-570.

KOHN A \& FERNANDES BMM. 1987. Comparative study of helminths parasites of fishes from Mogi Guassu river, collected during expeditions between 1927 and 1985. Mem Inst Oswaldo Cruz 82(4): 483-500.

KOHN A, FERNANDES BMM, MACEDO B \& ABRAMSON B. 1985. Helminths parasites of freshwater fishes from Pirassununga, SP, Brazil. Mem Inst Oswaldo Cruz 80(3): 327-336. 
KOHN A, FERNANDES BMM, PIPOLO HV \& GODOY MP. 1988. Helmintos parasitos de peixes das usinas hidrelétricas da Eletrosul (Brasil). II. Reservatórios de Salto Osório e de Salto Santiago, Bacia do rio Iguaçu. Mem Inst Oswaldo Cruz 83(3): 299-303.

KOHN A, MORAVEC F, COHEN SC, CANZI C, TAKEMOTO RM \& FERNANDES BMM. 2011. Helminths of freshwater fishes in the reservoir of the Hydroelectric Power Station of Itaipu, Paraná, Brazil. Check List 7(5): 681-690.

LAFFERTY KD. 1997. Environmental parasitology: what can parasites tell us about human impacts on the environment? Parasitol Today 13(7): 251-255.

LEITE LAR. 2017. Metazoários parasitos de Prochilodus lineatus (Valenciennes, 1837) provenientes do rio Batalha, Estado de São Paulo: ecologia e uso como indicadores de poluição aquática. Tese de mestrado, Universidade do Sagrado Coração (Unpublished).

LEITE LAR, PEDRO NHO, AZEVEDO RK, KINOSHITA A, GENNARI RF, WATANABE S \& ABDALLAH V. 2017. Contracaecum sp. parasitizing Acestrorhynchus lacustris as a bioindicator for metal pollution in the Batalha River, southeast Brazil. Sci Total Environ 575(1): 836-840.

LENT H \& TEIXEIRA DE FREITAS JF. 1948. Uma coleção de Nematódeos, parasitos de vertebrados do Museu de História Natural de Montevideo. Mem Inst Oswaldo Cruz 46(1): 1-71.

LOPRETTO EC. 1995. Annelida Hirudinea. In: Lopretto E \& Tell G (Dir), Ecosistemas de aguas continentales, Ediciones Sur, Argentina, $1^{\mathrm{a}}$ ed., p. 729-757.

LUDWIG JA \& REYNOLDS JF. 1988. Statistical Ecology: A Primer on Methods and Computing. Wiley-Interscience Publications, New York, $1^{\mathrm{a}}$ ed., 368 p.

LUQUE JL \& CHAVES ND. 1999. Ecologia da comunidade de metazoários parasitos de Pomatomus saltator (Osteichthyes: Pomatomidae) do litoral do Estado do Rio de Janeiro. Rev Bras Zool 16(3): 711-723.

MACHADO PM, TAKEMOTO RM \& PAVANELLI GC. 2005. Diplostomum (Austrodiplostomum) compactum (Lutz, 1928) (Platyhelminthes, Digenea) metacercarie in fish from the floodplain of the Upper Paraná River, Brazil. Parasitol Res 97(6): 436-444.

MACKENZIE K. 1999. Parasites as pollution indicators in marine ecosystems: a proposed early warning system. Marine Poll Bull 38(11): 955-959.

MADI RR \& SILVA MSR. 2005. Contracaecum Railliet \& Henry, 1912 (Nematoda, nisakidae): the parasitism related with the biology of three species of piscivorous fishes in the Jaguari reservoir, São Paulo State, Brazil. Rev Bras Zoociências 7(1): 7-14.

MAGURRAN AE. 2013. Measuring Biological Diversity. USA: Blackwell Publishing, $3^{\mathrm{a}}$ ed., 266 p.

MALACARNE PLC \& GODOI MMMM. 2012. Monogenéticos parasitos de Hoplias malabaricus (traira) e saúde animal na Amazônia ocidental. Rev Bras Ciên Amaz 1(1): 109-113.

MANCINI MA, BIOLÉ FG, SALINAS VH, GUAGLIARDO SE, TANZOLA RD \& MORRA G. 2014. Prevalence, intensity and ecological aspects of Contracaecum sp. (Nematode: Anisakidae) in freshwater fish of Argentina. Neotrop Helminthol 8(1): 111-122.

MARTINS ML, ONAKA EM \& FENERICK JRJ. 2005. Larval Contracaecum sp. (Nematoda: Anisakidae) in Hoplias malabaricus and Hoplerythrinus unitaeniatus (Osteichthyes: Erythrinidae) of economic importance in ocidental marshlands of Maranhão, Brazil. Vete Parasitol 127(1): 51-59.

MARTINS ML, SANTOS RS, MARENGONI NG, TAKAHASHI HK \& ONAKA EM. 2009. Seasonality of Eustrongylides sp. (Nematoda: Dioctophymatidae) larvae in fishes from Paraná River, Souht -Western Brazil. B Inst Pesca 35(1): 29-37.

MENEGUETTI DUO, LARAY MPO \& CAMARGO LMA. 2013. First report of Eustrongylides sp. Larvae (Nematoda: Dioctophymatidae) in Hoplias malabaricus (Characiformes: Erythrinidae) in Rondônia State, Western Amazon, Brazil. Rev Pan-Amaz Saúde 4(3): 55-58.

MINHOS LF, FERREIRA RO, VIEIRA KRI \& COSTA FES. 2016. Metazoan endoparasites occurrence of $H$. malabaricus in Mato Grosso do Sul Pantanal, and its importance in inspection of fish. Cadernos de Agroecol 11: 1-10.

MORAVEC F, PROUZA A \& ROYERO R. 1997. Some nematodes of freshwater fishes in Venezuela. Folia Parasitol 44(1): 33-47.

MORENO-ANCILLO A, CABALLERO MT, CABAÑAS R, CONTRERAS J, MARTIN-BARROSO JA, BARRANCO P \& LÓPEZ-SERRANO MC. 1997. Allergic reactions to Anisakis simplex parasitizing sea food. Ann Allergy Asthma Immunol 79: 246-250.

NEGRELLI DC, ABDALLAH VD \& AZEVEDO RK. 2018. Metazoan parasites of the lambari Astyanax altiparanae collected in the Batalha River, state of São Paulo, Brazil. Braz I Biol 78(3): 535-539.

NÚÑEZ MO, ARREDONDO NJ \& GIL DE PETIERRA AA. 2017. Adult trematodes (Platyhelminthes) of freshwater fishes from Argentina: a checklist. Revue suisse de Zool 124(1): 91-113. 
OLIVEIRA RD. 1994. Hábitos e comportamento alimentar da traíra, Hoplias malabaricus (Erythrinidae), em alagados de vazante, município de Santo Antonio de Leverger MT. Masters Dissertation. Instituto de Biociências da Fundação Universidade Federal de Mato Grosso, $1^{\mathrm{a}}$ ed., $120 \mathrm{p}$.

OLIVERO-VERBEL \& CABALLERO-GALLARDO K. 2013. Nematode and mercury content in freshwater fish belonging to different trophic levels. Parasitol Res 112(6): 2187-2195.

OWEN SE, BARBER I \& HART PJB. 1993. Low level infection by eye fluke, Diplostomum spp. affects the vision of threespined sticklebacks, Gasterosteus aculeatus. I F Biol 42(5): 803-806.

PAES JVK, CARVALHO ED \& SILVA RJ. 2010. Infection by Austrodiplostomum compactum metacercarie in fish from the Nova Avanhandava reservoir, Tietê River, São Paulo State, Brazil. Acta Sci Biol Sci 32(3): 273-278.

PAIVA MP. 1974. Crescimento, alimentação e reprodução da traíra, Hoplias malabaricus (Bloch) no Nordeste brasileiro. In: Barbieri G (1989) Dinâmica da reprodução e crescimento de Hoplias malabaricus (Bloch, 1794) (Osteichthyes, Erythrinidae) da Represa de Monjolinho, São Carlos/ SP. Rev Brasil Biol 6: 225-233.

PARAGUASSÚ AR \& LUQUE JL. 2007. Metazoan parasites of six fishes species from Lajes Reservoir in the State of Rio de Janeiro, Brazil. Rev Bras Parasitol Vet 16(3): 121-128

PARDO SC, ZUMAQUE AM, NOBLE HC \& SUÁREZ HM. 2008. Contracaecum sp. (Anisakidae) en pez Hoplias malabaricus, capturado en la Ciénaga Grande de Lorica, Córdoba. Rev MVZ 13(2): 1304-1314.

PAVANELLI GC, EIRAS JC \& TAKEMOTO RM. 2008. Doenças de peixes: profilaxia, diagnóstico e tratamento. $3^{\mathrm{a}}$ ed., Maringá: Eduem, 311 p.

PAVANELLI GC, MACHADO MH, TAKEMOTO RM, GUIDELLI GM \& LIZAMA M DE LOS AP. 2004. Helminth fauna of the fishes: diversity and ecological aspects. In: Thomaz SM, Agostinho AA \& Hahn NS (Eds), The Upper Paraná River and its Floodplain: Physical aspects, Ecology and Conservation. $1^{\text {st }}$ ed., Leiden, p. 309-329.

PELEGRINI LS, JANUARIO FF, AZEVEDO RK \& ABDALLAH VD. 2018. Biodiversity and ecology of the parasitic infracommunities of Loricaria prolixa (Siluriformes: Loricariidae) from the Tietê-Batalha Basin, SP, Brazil. Acta Sci Biol Sci 40(1): 1-8.

PÉREZ-CAICEDO A, LENIS C, VÉLEZ-ESCOBAR I \& BECHARAESCUDERO M. 2010. New record of Pseudosellacotyla lutzi (Digena: Faustilidae) in Hoplias malabaricus
(Pisces: Erythrinidae) Choco, Colombia. Investigación, Biodiversidad y Desarrollo 29: 110-112.

PORTELLA T, LOBON-CERVIA J, MANNA LR, BERGALLO HG \& MAZZONI R. 2017. ECO-morphological attributes and feeding habits in coexisting characins. J Fish Biol 90(1): 129-146.

POULIN R. 1998. Comparison of three estimators of species richness in parasite component communities. J Parasitol 84(3): 485-490.

POULIN R \& MORAND S. 2004. Parasite Biodiversity. Washington: Smithsonian Institution Books, $1^{\mathrm{a}}$ ed., 216 p.

PRADO CPA, GOMIERO LM \& FROEHLICH O. 2006. Spawning and parental care in Hoplias malabaricus (Teleostei, Characiformes, Erythrinidae) in the southern Pantanal, Brazil. Braz J Biol 66(2b): 697-702.

PRICE PW. 1980. The evolutionary biology of parasites. New Jersey: Princeton University Press, $1^{\mathrm{a}}$ ed., 256 p.

RAMALLO G. 1997. Spirocamallanus hilari (Nematoda, Camallidae) parásito de peces dulceacuícolas del embalse de Termas de Río Hondo, Santiago del Estero, Argentina. Bol Chil Parasitol 52: 67-70.

RAMOS IP, FRANCESCHINI L, ZAGO AC, ZICA EOP, WUNDERLICH AC, CARVALHO ED \& SILVA RJ. 2013. New hosts records and a checklist of fishes infected with Austrodiplostomum compactum (Digenea: Diplostomidae) in Brazil. Rev Bras Parasitol Vet 22(4): 511-518.

RODRIGUES LC, SANTOS ACG, FERREIRA EM, TEÓFILO TS, PEREIRA DM \& COSTA FN. 2017. Parasitologic aspects of traíra (Hoplias malabaricus) from the São Bento city, MA. Arq Bras Med Vet Zootec 69(1): 264-268.

ROHDE K. 1993. Ecology of marine parasites: An introduction to Marine parasitology. Wallinford: Cab International, $1^{a}$ ed., 298 p.

ROHDE K, HAYWARD C \& HEAP M. 1995. Aspects of the ecology of metazoan ectoparasite of marine fishes. Int J Parasitol 25(8): 945-970.

ROSIM DF, CECCARELLI PS \& SOUZA ATS. 2005. Parasitism of Hoplias malabaricus (Bloch, 1794) (Characiformes, Erythrinidae) by Quadrigyrus machadoi Fábio, 1983 (Eoacanthocephala, Quadrigyridae) at a pond, Aguaí, State of São Paulo, Brazil. Rev Bras Parasitol Vet 14(4): 147-153.

ROSIM DF, MENDONZA-FRANCO EF \& LUQUE JL. 2011. NeW and previously described species of Urocleidoides (Monogenoidea: Dactylogyridae) infecting the gills and nasal cavities of Hoplias malabaricus (Characiformes: Erythrinidae) from Brazil. J Parasitol 97(3): 406-417. 
RULL V. 2011. Neotropical biodiversity: timing and potential drivers. Trends Ecol Evol 26(10): 508-513.

SÃo PAULO. 2010. Plano de Manejo - Estação Ecológica de Bauru. Parte integrante do Termo de Compromisso de Compensação Ambiental (TCCA), no âmbito do licenciamento ambiental relativo à implantação do empreendimento "Linha de Transmissão de Energia Elétrica Londrina-Ararquara" - ATE Transmissora de Energia S.A., conforme processo SMA n 43.165/2005, 201 p.

SANTOS FS \& HEUBEL MTCD. 2008. Composição da comunidade ictiológica e biometria taxológica a lagoa de captação de água do DAE no rio Batalha (Bauru-SP). Salusvita 27(1): 29-44.

SANTOS RS, MARCHIORI N, SANTAREM VA, TAKAHASHI HK, MOURINO JLP \& MARTINS LM. 2012. Austrodiplostomum compactum (Lutz, 1928) (Digenea, Diplostomidae) in the eyes of fishes from Paraná river, Brazil. Acta Sci Biol Sci 34(2): 225-231.

SHAMSI S \& BUTCHER AR. 2011. First record of human anisakidosis in Australia. Med J Aust 194(4): 199-200.

SILVA FL, TALAMONI JLB, BOCHINI GL, RUIZ SS \& MOREIRA DC. 2009. Macroinvertebrados aquáticos do reservatório do rio Batalha para a captação das águas e abastecimento do município de Bauru, SP, Brasil. Rev Ambient Água 4(2): 66-74.

SNIS - SISTEMA NACIONAL DE INFORMAÇÕES SOBRE SANEAMENTO. 2016. Série histórica: informações sobre água e esgoto dos municípios brasileiros, 2016. Disponível em : http:// app.cidades.gov.br/serieHistorica/ergt;. Acessado em: $18 / 03 / 2017$.

SUEPAUL RB, MOHAMMED RS \& BASU AK. 2015. Infestation of Hoplias malabaricus (Teleostei, Characiformes, Erythrinidae) with nematode parasite Eustrongylides spp. in the Arena Dam of Trinidad, West Indies. Carib Nat 23: 1-7.

SURES B, NACHEV M, SELBACH C \& MARCOGLIESE DJ. 2017. Parasite responses to pollution: what we know and where we go in "Environmental Parasitology". Parasit Vectors 10(1): 1-9.

SZIDAT L. 1969. Structure, development and behaviour of new strigeatoid metacercariae from subtropical fishes of South America. J Fish Res Board Can 26(4): 753-786.

TAKEMOTO RM, PAVANELLI GC, LIZAMA MAP, LACER ACF, YAMADA FH, MOREIRA LHA, CESCHINI TL \& BELLAY S. 2009. Diversity of parasites of fish from the Upper Paraná River floodplain, Brazil. Braz J Biol 69(2): 691-705.
VIDAL-MARTINEZ VM, PECH D, SURES B, PURUCKER T \& POULIN R. 2010. Can parasites really reveal environmental impact? Trends Parasitol 26(1): 44-51.

VIEIRA KRI, VINCENTIN W, PAIVA F, POZO CF, BORGES FA, ADRIANO EA, COSTA FES \& TAVARES LER. 2010. Brevimulticaecum sp. (Nematoda: Heterocheilidae) larvae parasitic in freshwater fish in the Pantanal wetland, Brazil. Vet Parasitol 172(3/4): 350-354

WEIBLEN AM \& BRANDÃO DA. 1992. Survey of parasites of Hoplias malabaricus (Bloch, 1794) in Santa Maira County. Cienc Rural 22(1): 203-208.

WOLDA H. 1981. Similarity índices, sample size and diversity. Oecologia 50(1): 296-302.

YAMADA FH \& TAKEMOTO RM. 2017. How does host ecology influence sampling effort in parasite diversity estimates? A case study using Neotropical freshwater fishes. Acta Parasitol 62(2): 348-353.

YAMADA FH, TAKEMOTO RM \& PAVANELLI GC. 2007. Ecological aspects of ectoparasites from the gills of Satonoperca pappaterra (Heckel, 1840) (Cichlidae) from the upper Paraná River floodplain, Brazil. Acta Sci Biol Sci 29(3): 331-336.

ZAR JH. 1999. Biostatistical Analysis. New Jersey: PrenticeHall, 663 p.

ZUBEN CJV. 1997. Implicações da agregação espacial de parasitas para a dinâmica populacional na interação hospedeiro-parasita. Rev Saúde Públ 31(5): 523-530.

\section{How to cite}

GIÃO T, PELEGRINI LS, AZEVEDO RK \& ABDALLAH VD. 2020. Biodiversity of parasites found in the trahira, Hoplias malabaricus (Bloch, 1794), collected in the Batalha River, Tietê-Batalha drainage basin, SP, Brazil. An Acad Bras Cienc 92: e20180610. DOI. 10.1590/00013765202020180610 .

Manuscript received on June 15, 2018;

accepted for publication on November 5, 2018

\section{THAYANA GIÃO ${ }^{1}$}

https://orcid.org/0000-0002-9655-5603

\section{LARISSA S. PELEGRINI ${ }^{2}$}

https://orcid.org/0000-0001-8435-994X

\section{RODNEY K. DE AZEVEDO ${ }^{1}$}

https://orcid.org/0000-0002-0471-6079

\section{VANESSA D. ABDALLAH ${ }^{1}$}

https://orcid.org/0000-0001-6539-6091 
'Universidade do Sagrado Coração/USC, Pró-

reitoria de Pesquisa e Pós-graduação, Laboratório

de Ictioparasitologia, Rua Irmã Arminda, 10-50,

Jardim Brasil, 17011-160 Bauru, SP, Brazil

${ }^{2}$ Universidade Estadual Paulista/UNESP, Instituto

de Biociências de Botucatu, Rua Prof. Dr. Antônio

Celso Wagner Zanin, 250, Distrito de Rubião

Júnior, 18618-970 Botucatu, SP, Brazil

Correspondence to: Vanessa Doro Abdallah

E-mail:vanessaabdallahusc@gmail.com

\section{Author contributions}

Thayana Gião had a substantial contribution in the concept and study design. She contributed to data collection, data analysis and interpretation, in the manuscript preparation, in the critical revision and adding intellectual content. Larissa Sbeghen Pelegrini contributed to data collection, data analysis and interpretation, in the manuscript preparation, in the critical revision and adding intellectual content. Rodney Kozlowiski de Azevedo contributed to data collection, in the critical revision, adding intellectual content. Vanessa Doro Abdallah had a substantial contribution in the concept and study design. She contributed to data analysis and interpretation, in the critical revision and adding intellectual content.

\section{(c) BY}

